\title{
THE IMPORTANCE OF FLORA ADMINISTRATION IN THE MUNICIPALITY OF GUARUJÁ (SP), BRAZIL
}

\author{
Luiz Cláudio Souza de Oliveira ${ }^{1}$, Sidney Fernandes ${ }^{1} \bowtie$ (DD \\ ${ }^{1}$ UNIP - Universidade Paulista, ICS - Instituto Ciências da Saúde, Santos, São Paulo, Brazil.
}

Received 1 September 2021

Accepted 15 September2021

Published 30 September2021

\section{CorrespondingAuthor}

Sidney Fernandes,

sidney.fernandes@docente.unip.br

DOI

10.29121/granthaalayah.v9.i9.2021. 4198

Funding: This research received no specific grant from any funding agency in the public, commercial, or not-for-profit sectors.

Copyright: (C) 2021 The Author(s). This is an open access article distributed under the terms of the Creative Commons Attribution License, which permits unrestricted use, distribution, and reproduction in any medium, provided the original author and source are credited.

\section{ABSTRACT}

Objective: The study aimed to map, identify and catalog the tree species present in the municipality of Guarujá, Metropolitan Region of Baixada Santista, State of São Paulo, used in the afforestation of the municipality. The criteria for the choice of species by the city were evaluated, aiming through this survey, future proposals for better management in the administration of inclusion of urban flora; inclusion of native species, prioritizing species that are attractive to the region's fauna.

Methods: During the study, samples were taken in 5 (five) points of the city of Guarujá, with materials that present an equivalent representation of populations. The studies were carried out following seasonality, in order to observe the environmental influence on the distribution of plants.

Results: Twelve families, 28 genera and 29 species were identified in the samples carried out in 117 streets in 5 districts, being 57 streets in the Vila Áurea district, 24 streets in the Jardim Progresso district, 10 streets in the Santa Rosa district, 12 streets in the Pitangueiras district and 10 streets in the Virginia Garden District.

Conclusion: The interest in paying attention to plant species used in afforestation in the municipality of Guarujá is due to the fact that inappropriate afforestation is observed, sometimes planted by residents, without guidance and thus without technical criteria, thus creating a future problem, for example, causing problems urban areas such as pavement destruction, changes in the landscape and species that are not always attractive to fauna. Another fact that is also observed is the low diversity of species present, many of them exotic and not native to the region.

Keywords: Urban Afforestation, Floristic Survey, Municipality of Guarujá

\section{INTRODUCTION}

With the arrival of settlers in Brazil, the first biome they came across was the Atlantic Forest. This biome borders a large part of the Brazilian coast and was where the first settlers arrived, having the first contact with these lands, starting the colonization process. Brazil has several biomes, including the Atlantic Forest. Before the arrival of Portuguese settlers, in the 16th century, this forest formation occupied an extension of approximately 1.3 million $\mathrm{km} 2$ along the Brazilian coast, from Ceará to Rio Grande do Sul in the country. Along the coastline, distributed over 17 states, they are: Rio Grande do Sul, Santa Catarina, Paraná, São Paulo, Goiás, Mato Grosso do Sul, Rio de Janeiro, Minas Gerais, Espírito Santo, Bahia, Alagoas, Sergipe, Paraíba, Pernambuco, Rio Grande do Norte, Ceará and Piauí SOS Mata Atlântica (2014). Almost 72\% of the Brazilian 
population live in the Atlantic Forest, more than 145 million inhabitants in 3,429 municipalities IBGE (2010).

However, today the Atlantic Forest has lost almost all of its original coverage throughout Brazil's history, leaving only $8.5 \%$ of forest remnants above 100 hectares of what originally existed. Adding all the fragments of native forest above 3 hectares, we currently have 12.5\% SOS Mata Atlântica (2014), INPE (2014). One of the planet's highest priority regions for preservation. This forest is home to about $70 \%$ of Brazilian animals threatened with extinction Ribeiro (2009).

This study aims at a better management in the administration of inclusion of the urban flora in the municipality of Guarujá, State of São Paulo, belonging to the Metropolitan Region of Baixada Santista. The project aims to include native species, prioritizing attractive species for the region's fauna. The anthropogenic alteration occurs with the planting of exotic species that are not always attractive to fauna, in addition to causing urban problems such as the destruction of pavements and changes in the landscape. The idea would be the exchange or introduction of native species in the urban space, contributing as an attraction to the endemic fauna, which is often threatened with extinction. Assuming that the municipality of Guaruja is inserted in the Atlantic Forest, and this forest is inserted in the urban reality. The city of Guarujá has an area of $144,794 \mathrm{~km} 2$ and a population of 290,752 inhabitants IBGE (2010). The climate of the region is subtropical (Cfa) humid with an annual average between 18-250C. Among the endemic species of the municipality, the following were found: Abarema brachystachya Barneby \& Grimes, Aegiphila sellowiana Cham., Alchornea sidifolia Müll. Arg., A. triplinervea Müll. Arg., Allamanda catártica L., Allophyllus edulis A.St.-Hil., A.Juss. \& Cambess.) Hieron ex Niederl., Amaioua intermédia Mart., Ananas fritzmuelleri Camargo, Andira fraxinifolia Benth., Asclepias curassavica L., Astrocaryum aculleatissimum Burret, Avicenia schauveriana Stapf \& Leechm. ex Moldenke, Baccharis trimera (Less.) DC., Bathysa australis (A.St.-Hil.) K.Schum., Blechnum L. spp., Boehmeria caudata Sw., Bromelia antiacantha Bertol., Cabralea canjerana (Vell.) Mart., Calophyllum brasiliense Cambess., Campomanesia guaviroba (DC.) Kiaersk., Campyloneurum C. Presl. spp., Casearia sylvestris Sw., Casuarina L. spp., Cecropia glaziovii Snethl., C. pachystachya Trécul, Centrosema virginianum (L.) Benth., Cereus pernambucensis Lemaire, Chrysophyllum flexuosum Mart., Cissampelos andromorpha DC., Clusia criuva Cambess., Cordia curassavica (Jacq.) Roem. \& Schult., C. ecalyculata Vell., Coussapoa microcarpa (Shott) Rizzini, Croton floribundus Spreng., Cupania oblongifolia Mart., C. vernalis Cambess., Cyathea atrovirens (Langsd. \& Fisch.) Domin, Cyperus ligularis L., Cytharexylum myrianthum Cham., Dahlstedtia pentaphylla (Taub.) Burkart, Dalbergia ecastaphyllum (L.) Taub., D. frutescens (Vell.) Britton, Dendropanax cuneatum (DC.) Decne. \& Planch., Dickysonia sellowiana Hook., Dypsis lutescens (H. Wendl.) Beetje \& J. Dransf., Ecclinusa ramiflora Mart., Epidendrum fulgens Brongn., Erithrina L. spp., Eugenia brasiliensis Lam., E. leitonii Legr., E. ligustrina (Sw.) Willd., E. speciosa Cambess., E. stigmatosa DC., E. sulcata Spring ex Mart, Ficus insipida Willd., F. organensis (Miq.) Miq., Garcinia gardneriana (Planch. \& Triana) Zappi, Gleichenella pectinata (Willd.) Ching, Guapira opposita (Vell.) Reitz, Guarea guidonia (L.) Sleumer, Guarea macrophylla Vahl, Guatteria hillariana A.St.-Hil., Heliconia velloziana Emygdio, Heteropterys aenea Griseb., H. intermédia (A. Juss.) Griseb., Hibiscus L. spp., Hyeronima alchorneoides Allemão, Hymenaea courbaril L., Ilex dumosa Reissek, I. theezans Mart. ex Reissek, Inga edulis Mart., Inga laurina (Sw.) Willd., I. sellowiana Benth., Ipomoea cairica (L.) Sweet, Laguncularia racemosa (L.) C.F. Gaertn., Lantana undulata Schrank, Lasiacis ligulata Hitchc. \& Chase, Luehea grandiflora Mart. \& Zucc., Machaerium aculeatum Raddi, Manilkara subsericea (Mart.) Dubard, Matayba 
elaeagnoides Radlk., M. junglandifolia (Cambess.) Radlk., Maytenus littoralis Carvalho-Okano, M. robusta Reissek, Miconia cabussu Hoehne, M. cinnamomifolia (DC.) Naudin, M. cubatanensis Hoehne, M. latecrenata (DC.) Naudin, Mikania micrantha Kunth, Mollinedia schottiana (Spreng.) Perkins, M. ulleana Perkins, Myrcia fallax (Sw.) DC., M. multiflora (Lam.) DC., M. pubipetala DC. ex Guill., Nectandra oppositifolia Nees \& Mart., Ocotea pulchella (Nees) Mez, Oxypetalum banksii Roem. \& Schult., Paullinia micrantha Cambess., Pera glabrata (Schott) Poepp., Piper aduncum L., P. arboreum Aubl., P. cernuum Vell., Piptadenia gonoacantha (Mart.) J.F. Macbr., Posoqueria latifolia (Rudge) Schult., Psidium cattleyanum Sabine, P. guajava L., Psychotria cartagenensis Jacq., P. leiocarpa Cham. \& Schltdl., P. nuda (Cham. \& Schltdl.) Wawra, Pteris L. spp., Quesnelia arvensis (Vell.) Mez, Q. quesneliana (Brongn.) L.B. Sm., Rapanea ferruginea (Ruiz \& Pav.) Mez, R. umbellata (Mart.) Mez, Rizophora mangle L., Rollinia sericea Dunal, Schefflera angustifolia (Mart.) Mez, Schinus terebinthifolius Raddi, Schizolobium parahyba (Vell.) Blake, Selenicereus setaceus Rizz, Sida carpinifolia L.f., Siparuna brasiliensis (Spreng.) A.DC., Smilax elastica Griseb., Solanum pseudoquina A. St.-Hill., Sophora tomentosa L., Spartina Schreber sp., Syagrus romanzoffiana (Cham.) Glassman, Syzygium cumini L., Tabebuia cassinoides (Lam.) DC., Tapirira guianensis Aubl., Terminalia L. spp., Tetracera sellowiana Schltdl., Thelypteris Schmidel spp., Thespesia Sol. ex Corrêa spp., Tibouchina clavata (Pers.) Wurdack, T. mutabilis (Vell.) Cogn., T. pulchra Cogn., Tocoyena bullata (Vell.) Mart., Trema micranta (L.) Blume, Trichomanes L. spp., Urera bacífera (L.) Gaudich. ex Wedd, Vanilla Mill. sp., Virola bicuhyba (Schott ex Spreng.) Warb., Vitex polygama Cham., Aechmea lingulata (L.) Baker, Morus nigra L. e Terminalia catappa L. (the last three being exotic) Lorenzi (2010), Lorenzi (2014). We sought to inventory the urban flora. Real estate speculation, suppression of terrestrial ecosystems, predatory exploration are concerns, leading us to carry out this study.

The interest in the attention of plant species used in the afforestation of the municipality of Guarujá is due to the fact that inappropriate afforestation is observed, sometimes planted by residents, without guidance and thus without technical criteria, thus creating a future problem, for example, causing urban disturbances such as destruction of pavements, changes in the landscape and species that are not always attractive to fauna.

\section{MATERIALS AND METHODS}

During the study, samples were taken in 5 (five) neighborhoods in the city of Guarujá, with the most uniform coverage possible, with materials that present an equivalent representation of populations. The studies were carried out following seasonality, in order to observe the environmental influence on the distribution of plants. The municipality of Guarujá is located in the metropolitan region of Baixada Santista, State of São Paulo and comprises 9 (nine) municipalities. According to Ross (2003), the region presents a tropical climate. An attempt will be made to cover the geographic area in its maximum extent and as uniformly as possible. The work covered a geographic area in 5 (five) equidistant points, considering the ecosystem importance as mangrove area, riparian forest, port area and beach. During the samplings, the materials studied were of the most diverse sizes and habitats. Samplings were carried out in the urban area in order to select plants more suitable for urbanization. The equipment used in the samplings were: pruning saw, pruning pruner with extendable handle and pruning shears. The fixation and preservation of the materials were provided immediately after collection, still in the field, with a $70 \%$ alcohol solution, in glass or plastic bottles, in

relation to the fruits and seeds, while the leaves, flowers, roots and stems were made 
exsiccates with label describing the species name, collector, sampling site and sampling date. Immediate fixation prevents material decomposition by microbial agents. This preservation takes place in the sense of inventorying what was inserted in the urban fabric of the municipality of Guarujá. In the qualitative analysis, plants that presented reproductive structures were examined in order to more accurately identify the species, in the absence of these, the largest number of possible samples were analyzed to avoid misunderstandings. The aim was to observe the largest possible number of specimens of each type and taxonomically exhaust each sampling unit. Specimen's observations were performed using Carl Zeiss ${ }^{\circledR}$ magnifying glasses. For each characteristic, as many measures as necessary (and/or possible) were taken with the sole objective of accurately describing each species, variety or taxonomic form identified. Obviously, the minimum number of specimens observed depended on the size of populations available in the preparations. Individuals found only once during the study were only identified when they presented unequivocal diagnostic characters or when they did not present morphological variation or this was too small and considered negligible.

\section{RESULTS AND DISCUSSION}

Twelve families, 29 genera and 30 species were identified in the samples carried out in 5 districts, distributed as follows: 57 streets in district Vila Áurea, 24 streets in district Jardim Progresso, 10 streets in district Santa Rosa, 12 streets in district Pitangueiras and 10 streets in district Jardim Virginia.

\begin{tabular}{|c|c|c|c|c|c|}
\hline $\begin{array}{l}\text { FAMILIES AND } \\
\text { SPECIES }\end{array}$ & $\begin{array}{c}\text { VILA } \\
\text { ÁUREA }\end{array}$ & $\begin{array}{c}\text { JARDIM } \\
\text { PROGRESSO }\end{array}$ & $\begin{array}{l}\text { SANTA } \\
\text { ROSA }\end{array}$ & PITANGUEIRAS & $\begin{array}{l}\text { JARDIM } \\
\text { VIRGÍNIA }\end{array}$ \\
\hline ANACARDIACEAE & $\mathrm{x}$ & $\mathbf{x}$ & $\mathbf{x}$ & $\mathrm{x}$ & $\mathbf{x}$ \\
\hline $\begin{array}{l}\text { Artocarpus } \\
\text { heterophyllus }\end{array}$ & $\mathbf{X}$ & $\mathbf{X}$ & $\mathbf{X}$ & & \\
\hline Mangifera indica & $\mathbf{x}$ & $\mathbf{x}$ & & $\mathrm{X}$ & \\
\hline Schinus molle & & & & $\mathbf{X}$ & $\mathbf{X}$ \\
\hline Schinus terebinthifolius & $\mathbf{x}$ & $\mathbf{x}$ & $\mathbf{x}$ & $\mathrm{x}$ & $\mathbf{x}$ \\
\hline Spongias dulcis & $\mathbf{X}$ & $\mathbf{X}$ & & & \\
\hline ARALIACEAE & $\mathrm{X}$ & & $\mathbf{x}$ & $\mathbf{x}$ & \\
\hline Schefflera actinophylla & $\mathbf{X}$ & & $\mathbf{X}$ & $\mathbf{X}$ & \\
\hline ARECACEAE & $\mathbf{x}$ & $\mathbf{x}$ & $\mathbf{x}$ & $\mathrm{x}$ & $\mathbf{x}$ \\
\hline $\begin{array}{l}\text { Archontophoenix } \\
\text { cunninghamiana }\end{array}$ & & & & $\mathbf{x}$ & \\
\hline Cocos nucifera & $\mathbf{x}$ & $\mathbf{x}$ & $\mathbf{x}$ & $\mathbf{x}$ & $\mathbf{x}$ \\
\hline Dypsis lutescens & $\mathbf{X}$ & $\mathbf{X}$ & & & $\mathbf{X}$ \\
\hline Livistona chinensis & & & & $\mathbf{X}$ & \\
\hline Syagrus romanzoffiana & & & & & $\mathbf{X}$ \\
\hline BIGNONIACEAE & $\mathbf{x}$ & $\mathbf{x}$ & $\mathbf{x}$ & $\mathbf{x}$ & \\
\hline Handroanthus albus & $\mathbf{X}$ & $\mathbf{X}$ & & $\mathbf{X}$ & \\
\hline Tabebuia heptaphylla & $\mathbf{X}$ & & $\mathbf{x}$ & $\mathbf{X}$ & \\
\hline COMBRETACEAE & $\mathbf{X}$ & $\mathbf{X}$ & $\mathbf{X}$ & $\mathbf{X}$ & $\mathbf{X}$ \\
\hline Terminalia catappa & $\mathbf{x}$ & $\mathbf{x}$ & $\mathbf{x}$ & $\mathrm{x}$ & $\mathbf{x}$ \\
\hline FABACEAE & $\mathbf{X}$ & $\mathbf{X}$ & $\mathbf{X}$ & $\mathbf{X}$ & $\mathbf{X}$ \\
\hline Bauhinia variegata & & & $\mathbf{x}$ & $\mathbf{x}$ & \\
\hline $\begin{array}{c}\text { Calliandra } \\
\text { haematocephala }\end{array}$ & & $\mathbf{X}$ & & & \\
\hline Cassia fistula & $\mathbf{x}$ & $\mathbf{x}$ & & $\mathbf{x}$ & \\
\hline
\end{tabular}


The Importance of Flora Administration in The Municipality of Guarujá (Sp), Brazil

\begin{tabular}{|c|c|c|c|c|c|}
\hline Delonix regia & & & & $\mathbf{X}$ & \\
\hline Erythrina speciosa & $\mathbf{x}$ & & & & \\
\hline Mimosa scabrella & & & $\mathbf{X}$ & $\mathbf{X}$ & \\
\hline Paubrasilia echinata & & & & $\mathbf{x}$ & $\mathbf{X}$ \\
\hline MALPIGHIACEAE & $\mathbf{X}$ & $\mathbf{X}$ & & & \\
\hline Mapighia glabra & $\mathbf{X}$ & $\mathbf{X}$ & & & \\
\hline MALVACEAE & & & & $\mathbf{X}$ & \\
\hline Hibiscus tiliaceus & & & & $\mathbf{x}$ & \\
\hline MELASTOMATACEAE & & & & $\mathbf{X}$ & \\
\hline Tibouchina granulosa & & & & $\mathrm{X}$ & \\
\hline MORACEAE & $\mathbf{X}$ & $\mathbf{X}$ & $\mathbf{x}$ & $\mathbf{x}$ & $\mathbf{X}$ \\
\hline Ficus benjamina & $\mathbf{x}$ & $\mathbf{X}$ & $\mathbf{x}$ & $\mathrm{X}$ & $\mathbf{X}$ \\
\hline Morus nigra & $\mathbf{X}$ & & & & \\
\hline MYRTACEAE & $\mathbf{X}$ & $\mathbf{X}$ & & $\mathrm{x}$ & \\
\hline Eugenia uniflora & $\mathbf{X}$ & $\mathbf{X}$ & & $\mathbf{X}$ & \\
\hline Psidium guajava & $\mathbf{x}$ & $\mathbf{x}$ & & & \\
\hline Syzygium jambolanum & $\mathbf{X}$ & $\mathbf{X}$ & & & \\
\hline SAPOTACEAE & & & & $\mathbf{x}$ & \\
\hline Miusops coriaceae & & & & $\mathbf{x}$ & \\
\hline
\end{tabular}

Table 2 Location of sampling points in the municipality of Guarujá

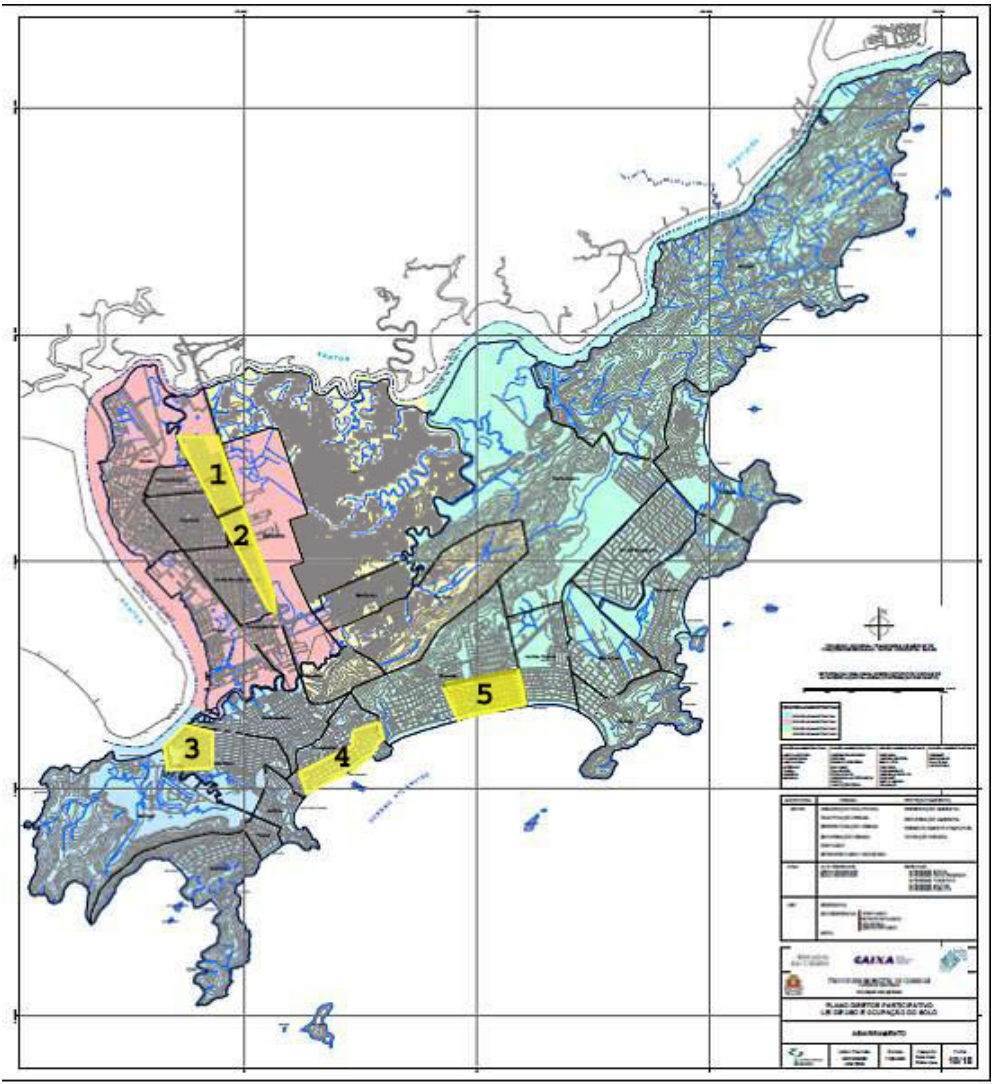

1 - District Vila Áurea.

2 - District Jardim Progresso.

3 - District Santa Rosa.

4 - District Pitangueiras.

5 - District Jardim Virgínia. 
Algumas espécies como a Terminalia catappa a qual ocorre em grande frequência no município, uma espécie exótica e caducifólia acabam causando entupimento de valetas nas vias públicas de alguns bairros, contribuindo com zonas de alagamentos e dependendo onde são plantadas, destruição de calçamentos. Há também grande frequência de uma espécie de figueira a Ficus benjamina a qual devido a suas raízes tabulares, acabam destruindo calçamentos e danificando tubulações, geralmente observam-se as mesmas, plantadas ao longo de canais onde se podem observar seus danos causados e em calçadas com espaço não adequado a árvores desse porte.

Outro fato observado foi a baixa diversidade de espécies presentes. Foram realizadas 29 amostragens em 113 ruas de 5 bairros, onde se observam muitas sem arborização enquanto outras, normalmente avenidas, um pouco mais arborizadas, mas com espécies não adequadas e majoritariamente exóticas como Terminalia catappa, Ficus benjamina, Cassia fistula, Mangifera indica e Artocarpus heterophyllus.

Acredita-se que este estudo trará novas contribuições para a ciência, já que até o momento, pouco se foi realizado em relação à biota local utilizada na arborização do município. Através destas informações, poder-se-á ter subsídios para estudos ecológicos de longa duração no sentido de preservação local.

\section{CONCLUSION}

The study was justified insofar as little is known in relation to care when introducing tree species into the urban space, which criteria are adopted, how much anthropic action may be influencing the distribution of these plants, if there has been loss of biodiversity and ecological importance. Despite the municipality being inserted in the Atlantic Forest, the urban vegetation is dissociated from the surroundings where you can find a few native species, as well as the cherry tree (Eugenia uniflora), the mastic tree (Schinus terebinthifolius) and guava (Psidium guajava). In most of the municipality, many adapted exotic species were found: sun hat (Terminalia catappa), benjamina fig tree (Ficus benjamina), jackfruit tree (Artocarpus heterophyllus), cassia (Cassia fistula). We have many beautiful native trees with landscape content that would greatly contribute to the recovery of the landscape and attractive to fauna, helping the seed dispersal of native species that should be introduced in the urban area, these aspects must be taken into account by the organization/management of vegetation urban, contributing to the environment. The importance of Environmental Education is based on the principle that residents, in their good will, seeking well-being, end up planting species along canals, sidewalks, etc., without realizing the importance of knowledge about root growth and crowns of the species planted by them, which end up causing future problems such as falling trees, destruction of pavements and destruction of underground pipes.

\section{REFERENCES}

Joly, A.B. (1993). Introdução à taxonomia vegetal. São Paulo : Editora Nacional. $777 \mathrm{p}$.

Lorenzi, Harri. (2010). Flora Brasileira - Arecaceae (Palmeiras). Editora Instituto Plantarum, São Paulo. 394p.

Lorenzi, Harri. (2014). Árvores Brasileiras. Editora Instituto Plantarum, São Paulo, vol. 01,6 a. ed. $384 p$. 
Lorenzi, Harri. (2014). Árvores Brasileiras. Editora Instituto Plantarum, São Paulo, vol. $02,4^{\mathrm{a}}$ ed. $384 \mathrm{p}$.

Lorenzi, Harri. (2014). Árvores Brasileiras. Editora Instituto Plantarum, São Paulo, vol. 03, 4⿳亠丷厂 ed. 384p.

Oliveira, E.C. (2003). Introdução à biologia vegetal. São Paulo: Editora da Universidade de São Paulo. 266p.

Raven, P.H., Evert, R.F. \& Eichhorn, S.E. (2001). Biologia Vegetal. Editora Guanabara Koogan: Rio de Janeiro. 6 ${ }^{\mathrm{a}}$ ed. 906p.

Ribeiro, M.C. et al. (2009). Brazilian Atlantic forest: how much is left and how is the remaining forest distributed ? Implications for conservation. Biological Conservation 142:1141-1153. from https://doi.org/10.1016/j.biocon.2009.02.021

Ross, J.L.S. (orgs). (2003). Geografia do Brasil. Editora da Universidade de São Paulo, São Paulo. (Série Didática no 3, 4⿳⺈冂a edição). 549p

\section{Email addresses}

IBGE (2010), ibge.gov.br/brasil/sp/guaruja/panoram.

INPE (2014), inpe.br/noticias/noticia.php?Cod_Noticia=3610. 2014.

SOSMataAtlântica (2014). sosma.org.br/wpcontent/uploads/2014/05/atlas_2012-2013_relatorio_tecnico_ 2014.pdf 